ORIGINAL

\title{
The effect of changing the pre-slaughter handling on bovine cattle DFD meat
}

\section{Efecto del cambio en el manejo antemortem sobre la presencia de carne DFD en ganado bovino}

\author{
Cristina Pérez-Linares, ${ }^{1}$ Ph.D, Alberto Barreras $S,{ }^{1}$ Ph.D, Eduardo Sánchez L, ${ }^{1}$ Ph.D, \\ Bárbara Herrera S, ${ }^{1}$ M.Sc, Fernando Figueroa-Saavedra, ${ }^{1 *}$ Ph.D.
}

Universidad Autónoma de Baja California. Instituto de Investigaciones en Ciencias Veterinarias. Km 3.5 Carr. a San Felipe, Fracc. Campestre. C.P. 21386, Mexicali, Baja California, México. *Correspondence: fernando_figueroa@uabc.edu.mx.

Received: September 2014; Accepted: February 2015.

\begin{abstract}
Objective. To evaluate the effect that a series of changes in the handling techniques used throughout the pre and post slaughter periods and during the handling of cooled carcass have on the presence of DFD (Dark, firm and dry) meat. Materials and methods. Odds ratios (OR) and confidence intervals were estimated applying logistic regression models. Data from 18 visits to the slaughterhouse regarding: animal handling on arrival, slaughter period, and carcass storage was obtained through the use of a questionnaire. A total of 572 carcasses were analyzed to determine DFD meat using $\mathrm{pH}$ and color $\left(\mathrm{L}^{*}, \mathrm{a}^{*}, \mathrm{~b}^{*}\right.$ and $\left.\mathrm{C}^{*}\right)$ measurements done on the Longissimus dorsi muscle. Results. Even after of the changes were made, the lairage period to slaughter continued to be a factor $(p<0.05)$ associated to the presence of DFD meat $(\mathrm{OR}=1.13)$. Of the complementary variables, the amount of time that cattle spent on the resting pens was associated $(p<0.05)$ to the presence of DFD meat $(O R=1.003)$. Conclusions. Regardless of the changes made in the ante mortem handling, a high frequency of DFD was found (39\%), suggesting a permanent audit program to detect other critical points in the supply chain.
\end{abstract}

Key words: Animal welfare, cattle, dark cutting meat (Source:CAB).

\section{RESUMEN}

Objetivo. Para evaluar el efecto de una serie de modificaciones en las técnicas de manejo usadas en el periodo pre y post-sacrificio y manejo de las canales en refrigeración en relación con la presencia de carne DFD (dura, firme y seca). Materiales y métodos. Se obtuvieron razones de desigualdad e intervalos de confianza empleando modelos de regresión logística. En 18 visitas a la planta de sacrificio, se aplicó un cuestionario obteniendo información sobre manejo de los animales desde su llegada a la planta, etapa de sacrificio y almacenamiento de las canales. Se estimó la frecuencia de carne DFD de analizar un total de 572 canales, registrando en el Longissimus dorsi pH y color (L*, a* b*, C*). Results. De las modificaciones realizadas, el tiempo de permanencia al sacrificio sigue siendo fue un factor asociado $(p<0.05)$ a la presencia de carne DFD $(O R=1.13)$. De las variables complementarias, el tiempo de espera en los corrales de descanso resultó correlacionado $(p<0.05)$ a la presencia de carne DFD (OR 1.003). Conclusiones. Independientemente de los cambios realizados en el manejo ante mortem, se encontró una alta frecuencia de carne DFD (39\%), sugiriendo un programa de auditoría permanente para detectar otros puntos críticos de la cadena logística.

Palabras clave: Bienestar animal, carne oscura para corte, ganado (Fuente:CAB). 


\section{INTRODUCTION}

The global commercialization of beef and its products and a growing demand for animal protein has resulted in a worldwide increase in the numbers of animals that are being slaughter (1), as result of this, the animal welfare problem related to transportation and pre slaughter of cattle has worsen (2). An important objective for the beef industry is to supply products that are both safe and of high quality and consumers are aware of the importance of this characteristics but they are also interested in the production process and on the environmental impact of the beef industry ( 3 ) so that cattle welfare has become a social issue and has broaden the concept of food quality (4).

In this context, along the production chain, animals are exposed to a series of factors and procedures that may cause them stress. The most common factors are: changes in weather, transport conditions, the way that animals are handled, the preslaughter waiting period, the stunning procedure, and the slaughter method (5). The size of any negative effect depends on the type, duration and intensity of the stressing factors before the animal is slaughter and how susceptible it is to them. These preslaughter adverse effects not only have an impact on animal welfare, but also have negative effects on the quality of the meat and on the income of the production chain participants, specifically in bovines there is evidence that preslaughter stress is detrimental to meat quality (6).

During the pre-slaughter period, stress and physical activity contribute to exhaust muscular glycogen, and as a result of this $\mathrm{pH}$ increases and beef changes its appearance so it may be classified as DFD (dark, firm and dry) also known as a dark cut. DFD meat is highly susceptible to bacterial problems because of the increased $\mathrm{pH}$ ( $\geq 5.8)$ (7). It is difficult to commercialize DFD meat because the consumer relates its dark color to poor storage conditions or assume that the beef is old (8).

Studies conducted in northwestern Mexico reported a $15.43 \%$ and $47.63 \%$ incidence of DFD meat during the summer and concluded that both pre slaughter and postmortem factors contribute to the presence of DFD meat, the lairage period before slaughter, relative humidity and the elapsed time period between slaughters were the relevant factor during the premortem period, while cooling temperature and the time that the carcass spent in the cooler were found to be important post mortem factors (9-11). Regarding the economic impact of DFD meat in

\section{INTRODUCCIÓN}

La globalización del comercio en los productos cárnicos en asociación con la creciente demanda de proteínas de origen animal ha dado lugar a un fuerte aumento en el número de animales sacrificados a nivel mundial (1), como resultado de esto, ha agudizado problemas de bienestar animal derivados del transporte y del manejo pre-sacrificio (2). Un objetivo importante de la industria cárnica es proporcionar productos seguros y de calidad a los consumidores, pero también incluye aspectos relacionados con las condiciones de producción y el impacto sobre el medio ambiente (3), recientemente, el bienestar animal se ha convertido en una preocupación social y un atributo dentro de un más amplio concepto de calidad de los alimentos (4).

En este contexto, durante la cadena productiva los animales están expuestos a una serie de factores y prácticas comerciales que pueden causar estrés en los animales. Estos factores son principalmente las variaciones climáticas, el transporte, el manejo, la espera pre-sacrificio, el aturdimiento y el sacrificio (5). La magnitud de cualquier efecto negativo está en función del tipo, duración e intensidad de los factores estresantes antes del sacrificio y la susceptibilidad individual de los animales Estos efectos adversos presacrificio no solo tienen impacto en el bienestar de los animales, sino que también tienen claras repercusiones en la calidad de la carne y en los beneficios económicos a los participantes de la cadena, específicamente, en bovinos existen evidencias que el estrés pre-sacrificio puede tener un importante efecto perjudicial sobre la calidad de la carne (6).

El estrés y la actividad física de los animales durante el manejo pre-sacrificio tienden a agotar el glucógeno muscular, lo que provoca un incremento en el $\mathrm{pH}$ y la obtención de una carne con apariencia firme, oscura y seca (DFD por sus siglas en inglés), también conocida como cortes oscuros. La carne DFD es mayormente susceptible al deterioro bacteriano debido al incremento del $\mathrm{pH}(\geq 5.8)$ (7). Esto dificulta comercializar la carne DFD ya que el consumidor asocia su color oscuro a carne vieja o almacenada en malas condiciones (8).

Estudios realizados en el Noroeste de México (Baja California) reportaron un $15.43 \%$ y $47.63 \%$ de presencia de carne DFD en verano y concluyeron que en ambos los factores pre y post sacrificio contribuyeron a la presencia de carne DFD, el tiempo de espera del ganado antes del sacrificio, humedad relativa, el tiempo promedio entre animal y animal para entrar al 
the same region it has been reported that as a result of this problem the carcass exhibits a $10 \%$ reduction of price so that its value decreases an average of 88.58 USD, if this amount is multiplied by the total number of carcasses produced between May and June of 2010 the estimated loss attributed to DFD meat is 5.272.946 USD (11).

In the state of Baja California slaughterhouses purchase the cattle on site and the seller is responsible for transporting the cattle to the plant, so if the animals are not handled properly during loading, transportation and unloading and as a result of this the carcass exhibits DFD meat, no economic sanction is received by either the transporter or the producer.

The objective of this study was to evaluate the effect that a series of changes in the handling techniques used throughout the pre and post slaughter periods and during the handling of cooled carcass have on the presence of DFD meat.

\section{MATERIALS AND METHODS}

Location. The study was done in the facilities of a (TIF) Federal Inspection Type Slaughter plant in the city of Mexicali, Mexico during the summer of 2009 (July-September). The region is geographically located at $32^{\circ} 40^{\prime} \mathrm{N}$ Latitude, $15^{\circ} 28^{\prime} \mathrm{W}$ Longitude, at an altitude of 10 meters above sea level, in Northwestern Mexico. Climate in this area can be described as dry desert with a $34.7^{\circ} \mathrm{C}$ average annual temperature of $\left(-5^{\circ} \mathrm{C}\right.$ in winter and $50^{\circ} \mathrm{C}$ in summer) $37 \mathrm{~mm}$ average annual rainfall and $>50 \%$ relative humidity.

Pre-slaughter handling. The carcasses studied came from cattle fattened in three feedlots. The cattle are crossbreed Zebu x European (Zebu 30 and European $70 \%$ ). The mean of final weight was $400 \mathrm{~kg}$. Transportation from the feedlots to the plant was on trucks equipped with cattle cages with a capacity for 50 animals, within a distance of 16 kilometers. The trip time between the feedlots and the slaughter plant took between 15 and 30 minutes and once the cattle arrives to the plant the animals are unloaded and place in waiting pens until slaughter which takes place between 0700 to $1500 \mathrm{~h}$ according to the time of arrival.

The slaughter plant can process between 350 and 400 animal at a rate of 40 to 45 animals per hour. The stunning is done by one trained operator but in case of absence he is substituted by an operator with no training or lesser experience. The unloading ramp is made out of concrete aturdimiento, mientras que la temperatura y las horas de almacenamiento de la canal antes de su embarque fueron factores asociados a la presencia de carne DFD (9-11). En relación al impacto económico de la carne DFD en la misma región se ha reportado que como resultado de este problema las canales exhiben una reducción del $10 \%$ del precio reduciendo su valor a un promedio de 88.58 USD, si esta cantidad es multiplicada por el número total de canales producidas entre mayo y junio del 2010, la pérdida estimada atribuida a la carne DFD es de 5.272.946 USD (11).

En el estado de Baja California las plantas de sacrificio compran el ganado en el sitio y el vendedor es el responsable de transportar el ganado a la planta, así que si los animales no son manejados de manera correcta durante el embarque, transporte y desembarque y como resultado de esto las canales exhiben DFD, ni el transportista ni el productor reciben una sanción económica.

El objetivo de este estudio fue evaluar el efecto de una serie de modificaciones en las técnicas de manejo usadas a través del periodo pre y post-sacrificio y durante el manejo de las canales en refrigeración en relación con la presencia de carne DFD.

\section{MATERIALES Y MÉTODOS}

Locación. Este estudio fue hecho en las instalaciones de una planta de Sacrificio Tipo Inspección Federal (TIF) en la ciudad de Mexicali, México, durante el verano de 2009 (Julio -Septiembre). La región está geográficamente ubicada a $32^{\circ} 40^{\prime}$ norte de latitud, $115^{\circ} 28^{\prime}$ oeste de longitud, y a una altitud de $10 \mathrm{~m}$ sobre el nivel del mar, en el noreste de México. El clima en esta aria puede describirse como desierto árido con una temperatura anual promedio de $34.7^{\circ} \mathrm{C}\left(-5^{\circ} \mathrm{C}\right.$ en invierno y $50^{\circ} \mathrm{C}$ en verano), $37 \mathrm{~mm}$ de precipitación anual promedio y $>50 \%$ de humedad relativa.

Manejo antemortem. Las canales estudiadas provenían de tres unidades de engorda intensiva. El ganado es cruza entre Cebú y Europeo (30\% Cebú y 70\% Europeo). El promedio de peso final fue de $400 \mathrm{~kg}$. El transporte desde las unidades de engorda intensiva a la planta fue realizado en camiones equipados con jaulas ganaderas con capacidad de 50 animales, en una distancia de $16 \mathrm{~km}$. El tiempo de transporte entre las unidades de engorda intensiva y la planta de sacrificio se llevó entre 15 y 30 minutos y una vez que el ganado llegó a la planta los animales fueron 
with no non-sliding floor and has the same width of the pens which are connected by a series of corridors to a resting area with six $84 \mathrm{~m}^{2}$ roofed pens with non-sliding floors, water is available for the animal but they are not feed. An electric prod is use to lead the animals from the pens to the slaughter area through a curved corridor which connects the resting area to the stunning box that measures $1.80 \mathrm{~m}$ high, 0.88 wide and $2.53 \mathrm{~m}$ long and has mechanism to hold the cattle head, the animal enters the box through a guillotine type door and is taken out through a door with an horizontal opening. The slaughter process followed the guidelines established by the federal authorities in the NOM-033-ZOO-1994 norm for the humane slaughter of domestic and animals wild. After being stunned by a captive bolt pistol (model USSS-1 Jarvis) the animal is raised and hanged by the leg with a hook and after being bleed the cattle go to the production line for processing, the process after stunning takes around 40 minutes. The carcasses are stored in refrigerated rooms with temperatures between -2 and $2^{\circ} \mathrm{C}(12)$.

Data collection. The information was obtained from 18 randomly selected groups of animals, one third of this group came from each of the feedlots. Starting from the arrival of the animals to the plant and until the carcasses where stored all relevant information was recorded. The changes on the handling system were done based on the results obtained from a previous study (13). These results are shown on table 1 . Due to their relation to the presence of DFD meat, information was obtained about the following handling procedures: use of the electric prod during unloading process, lairage period in the resting pens, temperature, relative humidity in the resting pens, number of persons that drive the cattle, use of the electric prod to drive the cattle, lairage time before slaughter, average time it takes to get into the stunning box, number of shots applied during stunning, descargados y puestos en corrales de espera hasta el sacrificio que se lleva a cabo entre las 0700 y 1500 h según la hora de llegada.

La planta de sacrificio puede procesar entre 350 a 400 animales por día en un rango de 40 a 45 animales por hora. Para el aturdimiento, un solo operador está capacitado y si llega a ser sustituido, es por un operador con poca o nula experiencia. La rampa de desembarque es de concreto y pisos no derrapantes con un ancho aproximado al ancho de las jaulas ganaderas que están conectadas por una serie de corredores a un área de descanso con 6 corraletas de $84 \mathrm{~m}^{2}$ techadas y pisos de concreto no derrapantes. Los animales tienen acceso libre al agua pero no reciben alimento. Se utiliza una picana eléctrica para arrear a los animales desde las corraletas hasta el sacrificio. Los animales son guiados por un corredor curveado que conecta desde el área de descanso hasta el cajón de aturdimiento ( $1.80 \mathrm{~m}$ alto $\times 0.88 \mathrm{~m}$ de ancho $\times 2.53 \mathrm{~m}$ de largo) que no cuenta con un sistema de fijación de cabeza. El acceso al cajón de aturdimiento es a través de una puerta tipo guillotina y con una puerta de salida de abertura horizontal. El proceso de sacrificio se sigue bajo los lineamientos establecidos por las normas federales en la NOM-033-ZOO-1994 sobre el sacrificio humanitario de los animales domésticos y silvestres. Después de ser aturdido con una pistola de perno cautivo (modelo USSS-1 JARVIS) es izado suspendido en un gancho colocado del miembro posterior, desangrado y transferido a la línea de producción para su procesamiento concluyendo alrededor de los 40 minutos después del sacrificio. Las canales son almacenadas en cuartos refrigerados a una temperatura de entre -2 a $2^{\circ} \mathrm{C}(12)$.

Recolección de datos. La información obtenida de 18 grupos seleccionada aleatoriamente, un tercio de este grupo provenía de cada unidad de engorda intensiva. Se inició con la llegada de los animales a la planta y hasta que las canales fueron almacenadas, toda la información relevante fue

Table 1. Odds Ratio (OR) values and 95\% Confidence Intervals for significant factors in Perez-Linares et al (13) joint with nature of each factor in previous study and changes made.

\begin{tabular}{|c|c|c|c|c|}
\hline Factor & $\begin{array}{l}\text { Nature in the } \\
\text { previous study }\end{array}$ & OR & $95 \% \mathrm{CI}$ & Change \\
\hline $\begin{array}{l}\text { Relative humidity in the } \\
\text { resting pens }\end{array}$ & $\begin{array}{l}\text { Greater than } 31 \% \text {, the cattle arrived at } \\
\text { noon and was slaughter the morning of the } \\
\text { following day }\end{array}$ & 31.60 & $4.17-239.18$ & $\begin{array}{l}\text { The animals were slaughter the morning of } \\
\text { the day of arrival. }\end{array}$ \\
\hline $\begin{array}{l}\text { Lairage period before } \\
\text { slaughter }\end{array}$ & $\begin{array}{l}\text { Equal or greater than } \\
30 \text { minutes }\end{array}$ & 17.96 & $1.06-303.48$ & $\begin{array}{l}\text { The period was reduced to less than } 30 \\
\text { minutes }\end{array}$ \\
\hline $\begin{array}{l}\text { Average time to enter in } \\
\text { stunning box }\end{array}$ & 1.52 minutes or more & 24.59 & $3.25-186.11$ & Less than one minute \\
\hline Carcass temperature & Between 5 and $10^{\circ} \mathrm{C}$ & 5.28 & $1.70-16.38$ & $\begin{array}{l}\text { The carcass are stored at least } 24 \text { hours in } \\
\text { the cold room }\end{array}$ \\
\hline Carcass storage time & 8 to 12 hours & 49.52 & $10.71-228.81$ & At least 24 hours of storage \\
\hline
\end{tabular}


average time between stunning and bleeding, room temperature during slaughter, the use of a cloth to cover the carcass, carcass storage time and if the carcass was sprayed with water during cold storage, so that it their association with of DFD meat was established.

Meat quality evaluation. The relative frequency of DFD meat was estimated by analyzing 572 carcasses taken at random during the study period. At $24 \mathrm{~h}$ after slaughtering the animals, the $\mathrm{pH}$ values and color variables measurements ( $\mathrm{L}^{*} \mathrm{a} *, \mathrm{~b}^{*}$ and $\mathrm{C}^{*}$ ) were taken from the Longissimus dorsi muscle between the $11^{\text {th }}$ and $12^{\text {th }}$ ribs allowing 30 minutes to pass before the measurements were taken, all the measurements were repeated three times. The $\mathrm{pH}$ was measure in center of the muscle using a Delta TRAK ISFET pH 101 (Delta TRAK, Inc., Pleasanton, CA., U.S.A.). Color was determined in the muscle surface through a Minolta CM-2002 spectrophotometer (Minolta Camera Co., Ltd.) provided with SCI (Specular Component Included), a D65 standard illuminant and $10^{\circ}$ standard observer function, where $L^{*}$ represents the lightness index $\left(0 \leq L^{*} \leq 100\right)$. Chroma measures the saturation of color and was estimated as $C^{*}=\left(a^{* 2}+b^{* 2}\right)^{0.5}(14)$. Beef meat was graded for according to the following categories: normal $\mathrm{pH}_{24}$ 5.4-5.8, L* 40-60 and $C^{*}>30$; and DFD beef $\mathrm{pH}_{24}>5.8$ (24 hours after slaughter), $L^{*}<40$ and $C^{*}<30$.

Statistical analysis. The present study was of the observational, prospective and transversal type. All the variables are of dichotomous nature. The sample size $(n=506)$ was determine using a simple randomized procedure with attributes, considering an infinite population, $95 \%$ confidence interval, $5 \%$ precision and maximum variance $(p=0.5)$, the sample included an additional 100 carcasses to improve the estimators. The occurrence of DFD meat was estimated as a relative frequency. A Chi squared test was used to perform the independent DFD frequency distribution test in the ith class of the jth handling variable. Odds Ratio (OR) was used as a measure of effect of the handling practice on the occurrence of DFD meat using the following formula

$\widehat{O R}=\frac{a / b}{c / d}=\frac{a d}{b c}$

where $a, b, c$ and $d$ represent frequencies for each class defined in a $2 \times 2$ contingency table. Confidence intervals at $95 \%$ were estimated for each OR considering: registrada. Los cambios en el sistema de manejo se hicieron basados en los resultados obtenidos de estudios previos (13). Estos resultados se muestran en la tabla 1 . Debido a su relación con la presencia de carne DFD, la información fue obtenida de acuerdo a los siguientes procedimientos de manejo: uso de la picana eléctrica durante el proceso de desembarque, periodo en corrales de descanso, temperatura ambiente, humedad relativa en los corrales de descanso, número de personas que arrean el ganado, uso de la picana eléctrica para arrear al ganado, tiempo promedio que lleva a entrar cada animal al cajón de noqueo, número de disparos aplicados durante el aturdimiento, tiempo promedio entre el aturdimiento y desangrado, temperatura del cuarto frío, uso de mantas para envolver a las canales, tiempo de almacenamiento de las canales y si la canales fue rociada con agua durante el almacenamiento, estableciendo su asociación con la presencia de carne DFD.

Evaluación de la calidad de la carne. La frecuencia relativa de carne DFD fue estimada utilizando 572 canales tomadas aleatoriamente durante el periodo de estudio. $24 \mathrm{~h}$ después del sacrificio, las medidas de valores de $\mathrm{pH}$ y variables de color ( $L^{*}, a^{*}, b^{*}$ y $\left.C^{*}\right)$ fueron tomadas del músculo Longissimus dorsi entre las costillas 11 y 12, esperando 30 minutos antes de tomar las medidas, todas las medidas fueron repetidas tres veces. El pH fue medido en el centro del músculo utilizando un Delta TRAK ISFET pH 101 (Delta TRAK, Inc., Pleasanton, CA., U.S.A.). El color se determinó en la superficie del músculo con un espectrofotómetro Minolta CM-2002 (Minolta Camera Co., Ltd.) con SCI (Componente Especular Incluido), un iluminador estándar D65 y $10^{\circ}$ de función de observador estándar, donde $L^{*}$ representa el índice de claridad $\left(0 \leq L^{*} \leq 100\right)$. Chroma mide la saturación de color y se estimó como $C^{*}=\left(a^{* 2}+b^{* 2}\right)^{0.5}(14)$. La carne fue calificada de acuerdo a las siguientes categorías: normal $\mathrm{pH}_{24}$ 5.4-5.8, L* 40-60 and C* > 30; y carne DFD $\mathrm{pH}_{24}>5.8$ ( 24 horas antes del sacrificio), L* $<40$ y C* $<30$.

Análisis estadístico. Este estudio fue de tipo observacional, prospectivo, y transversal. Todas las variables son de naturaleza dicotómica. El tamaño de la muestra $(n=506)$ se determinó utilizando un procedimiento aleatorio simple con atributos, considerando una población infinita, intervalo de confianza del 95\%, 5\% de precisión y varianza máxima $(p=0.5)$, la muestra incluyó 100 canales adicionales para mejorar los estimadores. La ocurrencia de carne DFD se estimó como frecuencia relativa. Una prueba chi-cuadrada se utilizó para llevar a cabo las pruebas de distribución de frecuencia independiente DFD en la i clase de la variable $\mathrm{j}$ de manejo. El cociente de probabilidad 
$I C 95 \%=\widehat{O R}^{1 \pm\left(Z_{\alpha} / \sqrt{\chi^{2}}\right)}$

and $Z_{a}=1.96, X^{2}$ was estimated using the following formula

$x^{2}=\frac{n(a d-b c)^{2}}{(a+c)(b+d)(a+b)(c+d)}$

OR value indicates magnitude of association between the predisposing component of a factor and positive DFD meat cases. The estimating of OR parameter from data samples organized in 2x2 frequency tables (Table 2).

Table 2. $2 \times 2$ frequency table, classified according to the risk factor, and the presence of DFD meat factors.

\begin{tabular}{cccc}
\hline & \multicolumn{3}{c}{ Sample } \\
\cline { 2 - 4 } Risk factor & DFD meat & Normal meat & Total \\
\hline Present & $\mathrm{A}$ & $\mathrm{B}$ & $\mathrm{a}+\mathrm{b}$ \\
Absent & $\mathrm{C}$ & $\mathrm{D}$ & $\mathrm{c}+\mathrm{d}$ \\
\hline Total & $\mathrm{a}+\mathrm{c}$ & $\mathrm{b}+\mathrm{d}$ & $\mathrm{n}$ \\
\hline
\end{tabular}

Components on the right side of the equation represent frequencies observed in each class defined in the $2 \times 2$ contingency table. Statistical assessment of associations was performed using OR and its confidence intervals, so that if $O R>1$ and a lower interval value $>1$ it indicates that the variables are associated. The SAS software 9.3 was used for all the statistical analyses.

\section{RESULTS}

The study found a $38.99 \%$ frequency of DFD meat $n=(223 / 572)$. The average values for $\mathrm{pH}$ and color for normal and DFD meat are showed on table 3 and the results of the association between the handling changes and DFD meat are presented in table 4, it can be seen that during the pre-slaughter period only two factors showed a significant association $(p<0.05)$ to DFD meat this are: the time spent by the cattle on the waiting pens with an OR of 1.003 and a mean of 115.2 102.15

Table 3. Mean values for $\mathrm{pH}$ and color components in carcasses graded as Normal and DFD meat.

\begin{tabular}{ccc}
\hline Variables & $\begin{array}{c}\text { Normal meat } \\
(\mathbf{n = 3 4 9 )}\end{array}$ & $\begin{array}{c}\text { DFD meat } \\
(\mathbf{n = 2 2 3})\end{array}$ \\
\hline pH & $5.74 \pm 0.08$ & $6.12 \pm 0.23$ \\
L* $^{*}$ & $36.29 \pm 2.98$ & $34.58 \pm 3.57$ \\
a* & $13.37 \pm 2.51$ & $13.90 \pm 2.21$ \\
b* & $6.53 \pm 2.16$ & $6.47 \pm 2.20$ \\
C* & $14.88 \pm 2.99$ & $15.38 \pm 2.72$ \\
H* $^{*}$ & $25.16 \pm 5.44$ & $24.13 \pm 5.79$ \\
\hline
\end{tabular}

(OR) fue utilizado para medir el efecto de las prácticas de manejo en la ocurrencia de carne DFD utilizando la siguiente fórmula:

$\widehat{O R}=\frac{a / b}{c / d}=\frac{a d}{b c}$

Donde a, b, c y d representan frecuencias para cada clase definida en una tabla de contingencia $2 \times 2$. Intervalos de confianza al $95 \%$ se estimaron para cada OR considerando:

$I C 95 \%=\widehat{O R}^{1 \pm\left(Z_{\alpha} / \sqrt{\chi^{2}}\right)}$

$y Z_{a}=1.96, X^{2}$ se estimó utilizando la siguiente forma

$x^{2}=\frac{n(a d-b c)^{2}}{(a+c)(b+d)(a+b)(c+d)}$

el valor OR indica la magnitud de asociación entre el componente de predisposición de un factor los casos de carne DFD positivos. La estimación del parámetro OR para muestras de datos se organiza en tablas de frecuencia $2 \times 2$ (Tabla 2 ).

Los componentes del lado derecho de la igualdad representan frecuencias observadas en cada una de las clases definidas en la tabla de contingencia $2 \times 2$. La valoración estadística de las asociaciones se realizó con los intervalos de confianza, de tal manera que los valores de OR $>1$ esto indica que las variables fueron asociadas. El paquete SAS versión 9.3 fue utilizado para todos los análisis estadísticos.

\section{RESULTADOS}

El estudio encontró una frecuencia de 38.99\% de carne DFD $n=(223 / 572)$. Los valores promedio para el pH color para carne normal y DFD se muestran en la tabla 3 y los resultados de la asociación entre los cambios en el manejo y la carne DFD se presentan en la tabla 4, se puede observar que durante el

Table 4. Mean values, Odds Ratio (OR) and $95 \%$ Confidence Intervals for Handling Changes proposed in association with DFD meat.

\begin{tabular}{|c|c|c|c|}
\hline Factor & Mean value & OR & $95 \% \mathrm{CI}$ \\
\hline $\begin{array}{l}\text { Relative humidity in the } \\
\text { resting pens }\end{array}$ & $34.06 \pm 13.80 \%$ & N.S. & \\
\hline $\begin{array}{l}\text { Lairage period in the } \\
\text { resting pens }\end{array}$ & $115.2 \pm 102.15 \mathrm{~min}$ & 1.003 & 1.001 .007 \\
\hline $\begin{array}{l}\text { Lairage period before } \\
\text { slaughter }\end{array}$ & $31.58 \pm 12.42 \mathrm{~min}$ & 1.130 & 1.0831 .192 \\
\hline $\begin{array}{l}\text { Average time to enter in } \\
\text { stunning box }\end{array}$ & $68.31 \pm 39.86 \mathrm{seg}$ & N.S. & \\
\hline Carcass temperature & & N.S. & \\
\hline Carcass storage time & & N.S. & \\
\hline
\end{tabular}

N.S. $=$ non-significant $(p>0.05)$ 
minutes and the waiting period to slaughter which showed a O.R. $=1.130$ and a mean of $31.58 \pm 12.42$ minutes, the relative humidity in the waiting pens showed no statistical significance. In the slaughter stage none of the variables were found to be associated to DFD meat this was also the case for all the cold storage variables.

\section{DISCUSSION}

The frequency of DFD meat were two times higher than reported in a previous study $(15.43 \%)(9)$, and are also much higher that what other researchers have reported (13.89\% con $\mathrm{pH}>5.8$ y $4.02 \%$ con $\mathrm{pH}>6.0$ ) (15). Some studies have found a relation between both cold temperatures and hot temperatures and pre slaughter stress (13), cattle are considered more sensitive to hot than to cool temperatures. Therefore, during the hot seasonal temperatures (over $25^{\circ} \mathrm{C}$ ) the ability of cattle to dissipate body heat to the environment is impaired imposing physiological stress on animals. Stressful conditions that lead to depletion of muscle glycogen reserves before slaughter may lead to higher meat ultimate $\mathrm{pH}$ values, and result in low residual levels of glucose (16).

The results of this study suggest that it is better to transport and unload the animals during the morning and not to extend the lairage period before slaughter for more than 4 hours, this is recommended because both the temperature and the relative humidity have not reach the highest values that may be seen on summer in the region $\left(50^{\circ} \mathrm{C}\right.$ with a relative humidity of $50 \%$ de H.R. at midday). Although the resting period allows the animal to recuperate from the stress that results from transportation, during this time the high temperatures had an important effect on the presence of DFD meat an important factor for this was that in the lairage pens the only spaces where animal take shelter from the sun have metal sheet roofs and concrete floors which provide a microclimate that contributes to an increase in temperature. Hot enviroments disrupt animal bevahiour and impose physicological stress, which activate glycogenolysis in skeletal muscle (16).

Other factors that influence the welfare of the animals and have a direct efect on the percentage of DFD meat are: the rotation of personnel in charge of stunning, the reason for this is that is common to substitute a skilled operator for one with lesser experience periodo antemortem sólo dos factores mostraron asociación significativa $(p<0.05)$ con la carne DFD y son: tiempo que el ganado estuvo en los corrales de espera con un OR de 1.003 y una media de $115.2 \pm 102.15$ minutos y tiempo de espera para el sacrificio que mostró un $\mathrm{OR}=1.130$ y una media de $31.58 \pm 12.42$ minutos, la humedad relativa en los corrales de espera no mostró diferencia significativa. En la fase de sacrificio ninguna de las variables fue asociada con carne DFD, al igual que con relación a las variables de almacenamiento en frío.

\section{DISCUSIÓN}

La frecuencia de carne DFD fue dos veces mayor que la reportada en el estudio anterior $(15.43 \%)$ (9), y también mucho más alta que la reportada por otros investigadores (13.89\% con $\mathrm{pH}>5.8$ y $4.02 \%$ con $\mathrm{pH}>6.0$ ). Algunos estudios han encontrado una relación entre las temperaturas frías y calientes y el estrés antemortem (13), el ganado se considera más sensible a temperaturas cálidas que frías. Por ende, durante las temperaturas de estación altas (más de $25^{\circ} \mathrm{C}$ ) se deteriora la capacidad del ganado de disipar calor corporal al ambiente imponiendo estrés fisiológico sobre los animales. Las condiciones estresantes que llevan a la depleción de reservas de glicógeno muscular antes del sacrificio puedes llevar a valores finales de $\mathrm{pH}$ en la carne más altos, y resultar en valores residuales bajos de glucosa (16).

Los resultados de este estudio sugieren que es mejor transportar y descargar los animales en la mañana y no extender el periodo de descanso ante del sacrificio por más de cuatro horas, esto se recomienda debido a que la temperatura y la humedad relativa no han llegado a sus más altos valores, como se puede ver en la región durante el verano $\left(50^{\circ} \mathrm{C}\right.$ con una humedad relativa de $50 \%$ al mediodía). Aunque el periodo de descanso permite que el animal se recupere del estrés que resulta del transporte, durante este tiempo las altas temperaturas han tenido un efecto importante en la presencia del carne DFD; un importante factor para esto fue que en los corrales de descanso el único lugar donde el animal puede protegerse del sol tienen techos de metal y pisos de concreto que proporcionan un microclima que contribuye a incrementar la temperatura. Los ambientes cálidos afectan el comportamiento del animal e imponen estrés fisiológico, lo que activa lo glicogenólisis en el músculo esquelético (16).

Otros factores que afectan el bienestar de los animales y tienen un efecto directo en el porcentaje de carne DFD son: la rotación del personal a cargo de la aturdimiento, la razón para esto es que un sustituto común para un operador entrenado es el de un operador sin experiencia y sin entrenamiento 
and without adequate training in this specific activity and also because of problems with the maintenance of the stunning equipment (17). In this study it was observed that design deficiencies of the shutte that impede the trap door to shut all the way down, also lack of maintenance of the stunning equipment and things that distract the cattle when it being driven are important factor of stress (18), when the plant has a good stunning equipment and the personnel in charge of stunning and bleeding the animals is well trained the efficiency of the insensibilization process increases and as a result of this (19), the frequency of DFD meat is reduced.

Slaughter plants are designed taking in to account conventional arquitectural criteria and because of this the plants have a design that facilitate the work that is done by humans but do not consider the behavioral needs of the animals (20), for this reason the animals are exposed to a great quantity of stressing stimuli like crowding, fastening, noise and unknown smells (21) all of which are factor for DFD meat (22). In one of the feedlots that provided animals for this study it was found that after unloading the animals are mixed with others in new groups and as a result of this fights for dominance take place causing stress (23), this situation should be avoided because it is an additional stress factor. Although the average waiting time before slaughter was reduced from 18 to 4 hours, the results of the study suggest that this is due to an excessive use of the electric prod to drive the cattle from the lairage pens to the shutte entrance, causing the animals to react in different ways, one of them is to try to escape increasing the possibility of injury when the animal fall, collide with the installations or with each other (21), because of this situation it is necessary to apply a audit system, so that welfare problems may be detected more efficiently (17) and it also recommended to increase the training programs of the personnel (19).

Another finding was that the carcass temperature in the refrigerated room was notabily lower when the storage time increase and that by increasing the storage time to the recommended 48 hours (22) the carcass temperature was optimal, before the recommended changes were made the carcasses were sold after only between 8 and 10 hours of cold storage.

In conclusion, after the changes were implemented in the plants a drop in the percentage of DFD meat was expected, however what was seen was a unexpected increase of DFD meat, which led to think that it is possible that during the loading of adecuado en esta actividad sin el entrenamiento adecuado a esta actividad específica y también debido a problemas con el mantenimiento adecuado del equipo de aturdimiento (17). En este estudio se observó que las deficiencias en el diseño del cajón de noqueo impide que la puerta cierre completamente, junto con un pobre mantenimiento al equipo de noqueo y cosas que distraen al ganado cuando éste es conducido son un importante factor de estrés (18), cuando la planta tiene un buen equipo de aturdimiento y el personal a cargo de aturdir y desangrar está bien entrenado, la eficiencia del proceso de aturdimiento incrementa (19), y como resultado disminuye la frecuencia de carne DFD.

Los mataderos se diseñan tomando cuenta criterios convencionales de arquitectura y es por esto que las plantas tienen un diseño que facilita el trabajo hecho por humanos pero que no considera las necesidades de comportamiento de los animales (20), por esta razón los animales están expuestos a una gran cantidad de estímulos estresantes como el amontonamiento, aseguramiento, ruidos y olores desconocidos (21), dos factores para carne DFD (22). Los animales en una de las unidades de engorda intensiva que fueron parte del estudio en el matadero que son parte de este estudio se encontró que después de descargar los animales estos son mezclados con otros nuevos grupos, como resultado de esto se causan peleas por dominancia que ocasionan estrés (23), esta situación debería evitarse ya que es un factor adicional de estrés. Aunque el tiempo promedio de espera antes del sacrificio se redujo de 18 a 4 horas, los resultados de este estudio sugieren que esto es debido a un uso excesivo de la picana eléctrica para llevar el ganado desde los corrales de descanso hasta la entrada del shutte, causando que los animales reaccionen en diferentes maneras, una de ellas es tratar de escapar incrementando la posibilidad de lesiones si el animal se estrella con las instalaciones o se estrellan entre sí (21), debido a esta situación es necesario aplicar un sistema de auditoría, para que los problemas de bienestar puedan detectarse de manera más eficiente (17) Y también se recomienda incrementar los programas de entrenamiento del personal (19).

Otro hallazgo fue que la temperatura de las canales en el cuarto frío fue notablemente disminuyendo cuando el tiempo de almacenamiento incrementó y por el incremento del tiempo de almacenamiento a las 48 horas recomendadas (22) la temperatura de la canal fue óptima. Antes de que se implementaran los cambios recomendados las canales eran vendidas sólo después de 8 a 10 horas de almacenamiento en frío.

En conclusión, después de que se implementaran los cambios en las plantas se esperaba que el porcentaje de carne DFD disminuyera, sin embargo, el aumento en la presencia de carne DFD tan inesperado indica que es posible que en el embarque de los animales 
the animals in the feedlot and during transport other stressing factors are present. Because of the increase cases of DFD meat found by this study after the changes done in the handling system, it is recommended to extend the research and include the period between loading and arrival of the cattle to the slaughter plant, so that it is possible to determine which are the relevant handling factors that contribute to the problem of DFD meat and to also increase the welfare of animals that are going to be slaughter trough adaptations made in the facilities and better training of the personnel.

\section{Acknowledgments}

The authors which to thank the personnel of the TIF slaughter plant for all the aid given to carry out this study. en las unidades de engorda intensiva y durante el transporte se presenten otros factores de estrés. Debido al incremento de casos de carne DFD en este estudio luego de realizar los cambios en el sistema de manejo, se recomienda extender la investigación e incluir el periodo entre el embarque y la llegada de los animales a la planta de sacrificio, esto hace posible determinar cuáles son otros factores de manejo relevantes que contribuyen al problema de la carne DFD y así, incrementar el bienestar de los animales que van a ser sacrificados a través de adecuaciones realizadas en las instalaciones y mejorando la capacitación al personal.

\section{Agradecimientos}

Los autores quisieron agradecer al personal del matadero TIF por toda la ayuda prestada durante este estudio.

\section{REFERENCES}

1. Blokhuis HJ, Keeling LJ, Gavinelli A, Serratosa J. Animal welfare's impact on the food chain. Trends Food Sci Tech 2008; 19(Supl 1):S79-S87.

2. Miranda de la Lama GC, Villaroel M, María GA. Livestock transport from the perspective of the pre-slaughter logistic chain: a review. Meat Sci 2014; 98(1):9-20.

3. Sepúlveda W, Maza MT, Mantecón AR. Factors that affect and motivate the purchase of quality-labelled beef in Spain. J Meat Sci 2008; 80(4): 282-289.

4. María GA. Public perception of farm animal welfare in Spain. Livest Sci 2006; 103(3):250-256.

5. Apple JK, Kegley EB, Galloway DL, Wistuba TJ, Rakes KL. Duration of restraint and isolation stress as a model to study the darkcutting condition in cattle. J Anim Sci 2005; 83(5):1202-1214.

6. Fergunson DM, Warner RD. Have we underestimated the impact of the preslaughter stress on meat quality in rumiants? Meat Sci 2008; 80(1):12-19.

7. Van de Water G, Verjans F, Geers R. The effect of short distance transport under commercial conditions on the physiology of slaughter calves; $\mathrm{pH}$ and colour profiles of veal. Livest Prod Sci 2003; 82(2-3):171-179.
8. Mounier L, Dubroeucq H, Andanson S, Veissier I. Variations in meat $\mathrm{pH}$ of beef bulls in relation to conditions of transfer to slaughter and previous history of the animals. J Anim Sci 2006;84(6):1567-1576.

9. Pérez-Linares C, Figueroa-Saavedra F, Barreras-Serrano A. Management factors associated to DFD meat in bovine on desertic climate. Arch Zootec 2008; 57(220):545-547.

10. Sotelo-Flores AP. Evaluación de cambios en las prácticas de manejo y su asociación con la presencia de carne DFD en bovinos. [Tesis de maestría]. Mexicali (BC): Universidad Autónoma de Baja California; 2008.

11. Leyva-García IA, Figueroa-Saavedra $F$, Sánchez-López E, Pérez-Linares $C$, Barreras-Serrano A. Impacto económico de la presencia de carne DFD en una planta de sacrificio Tipo Inspección Federal. Arch Med vet $2012 ; 44: 39-42$.

12. Miranda de la Lama GC, Leyva IG, BarrerasSerrano A, Pérez- Linares C, Sánchez-López E, María GA, Figueroa-Saavedra F. Assessment of cattle welfare at a comercial slaughter plant in the northwest of México. Trop Anim Health Prod 2012; 44(3):497-504.

13. Pérez-Linares C., Figueroa-Saavedra F, Barreras-Serrano A. Relationship between management factors and the occurrence of DFD meat in cattle. J Anim Vet Adv 2006; 5(7):578-581. 
14. Young SK, Seok HY, Young HS, Sung HL. Effect of season on color of Hanwoo (Korean native cattle) beef. J Meat Sci 2003; 63(4):509-513.

15. Mach N, Bach A, Velarde A, Devant M. Association between animal, transportation, slaughterhouse practices, and meat $\mathrm{pH}$ in beef. Meat Sci 2008; 78(3):232-238.

16. Kadim IT, Mahgoub O, Al-Ajmi DS, Al-Maqbaly RS, Al-Mughiry SM, Bartolome DY. The influence of season on quality characteristics of hot-boned beef $\mathrm{m}$. Longissimus thoracis. J Meat Sci 2004; 66(4):831-836.

17. Grandin T. Auditing animal welfare at slaughter plants. J Meat Sci 2010; 86(4):56-65.

18. Miranda de la Lama GC. Transporte y logística pre-sacrificio: principios y tendencias en bienestar animal y su relación con la cálida de la carne. Vet Méx 2013; 44(1):31-56.

19. Gregory NG, Lee CJ, Widdicombe PJ. Depth of concussion in cattle shot by penetrating captive bolt. J Meat Sci 2007; 77(4):499-503.
20. Miranda de la Lama GC, Liste G, Villaroel M, Escós J, María GM. Critical points in the preslaughter logistic chain of lambs in Spain that may compromise the animal's welfare. Small Ruminant Res 2010; 90(1-3):174-178.

21. Nanni-Costa L, Lo Fiego PD, Tassone F, Russo $\mathrm{V}$. The relationship between carcass bruising in bulls and behaviour observed during preslaughter phases. Vet Res Commun 2006; 30(9):379-381.

22. Chanona, J, Alamilla L, Mendoza E, Gutiérrez GF. Refrigeración y congelamiento. En: Hui, YH, Guerrero I, Rosmini M. Ciencia y Tecnología de Carnes. México: LIMUSA; 2006.

23. Mounier L, Veissier I, Andanson S, Delval E, Boissy A. Mixing at the beginning of fattening moderates social buffering in beef bulls. Appl Anim Behav Sci 2006; 96(3-4):185-200. 